\title{
The Impacts Of Information And Communication Technology (ICT) On The Teaching And Learning Science And Mathematics For Sustainable Development.
}

\author{
Oni, N.O., Raji, M.T., Olayiwola, M.A., Adeniran, P.O. \& Fasasi, S.K. \\ ${ }^{1}$ Department of Mathematics and Statistics, The Polytechnic Ibadan, Saki Campus, Oyo State, Nigeria. \\ ${ }^{2}$ Department of Science Laboratory Technology, The Polytechnic Ibadan, Saki Campus, Oyo State.
}

\begin{abstract}
Information and Communication Technology (ICT) is relatively a new area in human development that combines the technology of various electronic devices. The use of them and the distribution of these facilities with reference to the geographical location are made known. The paper highlights the concept of ICT, the impact of ICT in the teaching and learning context, the role of ICT in the teaching and learning of Science and Mathematics. The various implications of ICT for sustainable development are also exhaustively discussed. The paper then concludes with adequate recommendations to ensure widespread use of ICT nationwide.

Keywords: Impacts, ICT, Science, Mathematics, Sustainable Develpoment,
\end{abstract}

\section{Introduction}

The emergence of Information and Communication Technology (ICT) in education has transformed teaching and learning to a more viable and effective method and would likely set the standard for the future. Iloeje (2002) asserts that the interactivity in education and learning techniques brought about by the new technology has created a whole new learning environment and transformed the relationship among science teachers and the learners. The result is that the ways and means of packaging and delivering information have changed. Information users desire a wave of service different from the traditional paper based. Liverpool (2001) notes that this new wave of ICT has affected Universities, Polytechnics, Monotechnics and Colleges of Education greatly as an information provider in the society. These institutions struggle to maintain their credibility in the provision of adequate materials for research, teaching and learning through the acceptance and use of information and communication technology (ICT).

There is no doubt that Information and Communication Technology has carved its niche in every sphere of Nigeria's polity. Information and Communication Technology has been defined as a broad based technology (including its methods, management and application) that supports the creation, storage, manipulation and communication of information (French, 1996). According to Hang and Keen in Nworgu (2007), information technology means a set of tools that helps you work with information and perform tasks related to information processing. The definition of French is more encompassing than that of Nworgu, which was limited to information processing and did not extend to the communication of ICT. Actually, the term originated as Information Technology (IT) until recently when it was thought that the communication component ought to be highlighted because of its significance. It was then that the concept transformed to Information and Communication Technology (ICT) (Olusanya and Oloyede, 2003).

\section{Concept of Information Communication Technology}

The ICT revolution is a by-product of the digitization era; it implies processing, storage and retrieval of information in codes form, and its transportation and/or exchange between sources/terminals electronically (Ige, 2001). Rowlay (1985) in Ukpebor (2006) notes that Information and Communication Technology ICT is the acquisition, processing, storage and dissemination of vocal, pictorial, textual and numerical information by a micro electronics- based combination of computing and telecommunications. Abayai (2004) contends that Information and Communication Technologies are vast web of high speed digital communication networks world wide or national in scope and accessibility by the general public. This Information Communication Technology has a strong impact on economic, education and social life of the citizens of a nation. Rahman (2002) defines information and communication technology (ICT) as the technology of creation, processing, storage, electrical and electronic (hardware), and electronic computing (software), as well as the internet and global system of mobile communication (GSM). The digital computer, a device that processes data to produce information plays a vital and central role in information and communication technology. Abifarina (2003) states that information and communication technology (ICT) also refers to the different infrastructure used in creation, storage, processing, communications and dissemination of information and their application and the numerous services these infrastructures render. However, the communication aspect of ICT is assuming more significance 
now than ever before hence, it is now more appropriate to use the expression information and communication technology (ICT) rather than mere information technology which has become the back bone of the new information- based global economy.

\section{The Impacts of ICT on the Teaching and Learning Context}

The success of any teaching and learning process depends on the effectiveness of communication. Information and communication technology can play the role of patience teacher - it consistently works at the learners' space; assisting him to acquire sets of information, skills, facts etc. (Ojo. 2005). A teacher conveys his thoughts, states his facts, poses problems and evaluates his students by means of communication (Asiriwa, 2003). The teacher can take advantage of the dynamism of ICT to demonstrate sound difficult concepts, theories and principles. This will give meaning to his classroom instruction and thus enhance his teaching and make his class presentation an exciting one. Some programmed instruction software are capable of feeding back very accurate information to teachers about the individual progress of all students in the class. In this setting, the computer reinforces the correct answers to the numerous questions posed. Today, the development in information and communication technology has brought about evaluation of information and communication technology, which is ever growing and continuously affecting every aspect of human endeavour be it education, economy, politics etc (Abifarina, 2003). Thus, the teacher using ICT in his class will be able to present a wellplanned set of lessons and the students will experience these lessons in an exciting environment. Ojo (2005) notes that the misconception that the computer will replace the teacher and thus render him redundant does not arise; all the computer does is to reinforce and enhance the teacher's lessons. ICT can help students to become independent learners capable of developing critical thinking and problems-solving strategies, collaborative works and inquiry. It allows for information searches, computer modeling, team-work, brain-storming and revision. Teachers can use computers to make learning experiences more effective and to offer students access to a variety of learning tools, expert opinions and alternative viewpoints. Idahosa and Ero (2005) citing Iji (2003) states that in computer assisted instruction; lessons production is guided by the learners' knowledge skills understanding, expectations as well as motivation. He believed that it is the learners' educational needs, not the available computer hardware or software that determine the nature of the lesson. This implies that a computer is not an instructor in itself but rather a mere vehicle of instruction. It is a clear secret that the computer offers powerful features for facilitating learning. In summarizing the impact of ICT in teaching and learning generally, Akano (1999) in Utor and Agbi (2006) has the following to say "Computer which is a major focal point in information and communication technology can be used to drill and practice. Here, a programme is designed to augment classroom teaching instruction, learning and research; it provides the students with a variety of questioning exercise." Telecommunication is another useful development in information technology, in teleconferencing, scientists of great repute can sit in their respective offices or research centres and partake in conference without necessarily visiting each other.

\section{The Impacts of ICTon the Teaching and Learning of Science and Mathematics}

Ojurumeh (2003) in Ukpebor (2006) describes laboratory in science and mathematics as a special equipped room which contained instructional materials and equipment to facilitate learning. In fact, science and mathematics laboratories act as resources centres for teaching and learning sciences. The laboratory provides students with experiences that are needed in order to acquire the concept/principles and generalization in sciences. This may involve performing an experiment, viewing a film, playing a game, discussion, reading, programming a computer, building a model, solving a problem, making a survey, drawing a design, drawing a graph, presenting a science and mathematical skills, completing a test, proving a theorem practically etc. According to Ukpebor (2006) the computer which is an essential component of information and communication technology is increasingly becoming an essential equipment of instrumentation, measurement and experimentation in science and mathematics laboratories. He was of the view that the major function of computer in science and mathematics laboratory is data acquisition, data handling, and analysis.

\section{Implication of ICT for Sustainable Development}

Information and communication technology (ICT) play a critical role in socio-economic development because they are being used to achieve sustainable development. The word sustainable described by Longman Dictionary of Contemporary English means to continue or lasts for a long time. ICT sustains development by enhancing the following:

(a) Improvement of institution information management, inter-institutional communication, communication between regional or state cooperation institutions and their organizations thereby facilitate integration.

(b) Promote trade, financial cooperation, agricultural development, educational research, environmental protection etc.

(c) ICT could also catalyze transborder data flows bringing down barriers to personal communications and removing the constraints of national boundaries, physical disabilities as well as distance. By providing access to network, ICT reduces the costs of international communication among countries. 
Osiakwan (2002) observes that to a large extent, information and communication technologies are a major tool for sustaining development and this is evident in the numerous examples from around the world in educational resources availability, agricultural production, health delivery, good governance and economic emancipation. He was of the view that environmental sustainability cannot be achieved fast without a good database of information and knowledge about the environment and deploying the necessary technological schemes prevent pollution and degradation of the natural resources that we have. Mutula (2002) affirms that ICT was essential in the sustainable development when it was used to manage the electoral process in South Africa during the 1999 parliamentary and presidential elections. It was used for vote registration, the polling process, relaying of ballot collect and verification, and relaying of results of the election throughout the country.

\section{Recommendations}

ICT, indeed has enormous usefulness in modern development. But it is sad to note that in Nigeria, we are yet to fully harvest these pleasant fruits of ICT to enable us position our nation properly. For this, the following recommendations are made:

(1). The curriculum of Nigeria education system needs to identify priority of the country so as to be able to offer relevant ways of helping students to achieve competence in handling ICT. To meet their educational as well as their individual development needs.

(2). Government at all levels should encourage the use of ICT in schools by providing the necessary infrastructure and manpower.

(3). The Ministry of Education should organize seminars, workshop and conferences for teachers in order to equip them with relevant skills needed for capacity building.

(4). The government should establish national ICT centres to be in charge of information and communication technology in the country. This body should be charged with all issues concerning ICT including ways of improving adequate statistics and data of various ministries and establishments in the country.

(5) Science teachers should be given opportunity to attend seminars and conferences where they will upgrade their knowledge on the use of ICT in the classroom

\section{Conclusion}

Information and Communication Technology (ICT) is an all-pervading revolution affecting all aspects of human life. In the teaching-learning context, ICT serves to remove physical boundaries that restrict learning to any specific location and permits the teacher to access new information sources, thus enhancing his knowledge. Science and Mathematics subjects are the subjects in which students' record poor performance both at the internal and external examinations in recent time. In order to solve this problem, new areas have been discovered by the scientists to break this "rock" that had hitherto seemed unbreakable. This is where the use of information and communication technology as instructional aids comes into focus.

\section{References}

[1]. Abayai, T. (2004) Vision and mission of ICT education for sustainable development in Nigeria. In Ashituabe, G. A. and Kolo, I. A. Eds) Education for sustainable development in Nigeria. Minna: Niger State College of Education.

[2]. Abifarina, M. S. (2203) Information and Development of distance Education programme in Nigeria in the $21^{\text {st }}$ Century. Nigeria Journal of Education Studies

[3]. Asiriwa, D. O. (2005) The use of ICT as an instructional material in Science Education. A paper presented at the Annual National Conference of School of Science, College of Education Ekiadotor-Benin.

[4]. Idihosa, O. M. and Ero, N. R. (2005). The use of ICT in Mathematics Education. A paper presented at the Annual National Conference of School of Science, College of Education Ekiadotor-Benin.

[5]. Ige. B. (2001) African Response of ICT Revolution, Paper presented at the African Technology Policy Study Network (ATPS) Annual Workshop. October 29 - November 2, Nairobi.

[6]. Iloeje, M. U. (2002) The challenges, innovations in Technology pose to Libraries and librarians. Paper delivered at the Plenary Session of the NLA $39^{\text {th }}$ National Conference and AGM. Newsletter: A biannual pub. On NLA 13

[7]. Liverpool, L. S. O. (2001) Information and Communication Technology (ICT) and University Administration. Paper presented at the Annual General Meeting of the Committee of the Association o Nigerian University Professional.

[8]. Mutula, M. (2002) Supporting democracy with ICTs: South Africa independent Electoral Commission. Open society initiative. Information Communication Technologies and Civil Society Consultative Meeting.

[9]. Ojo, M. O. (2005) Information and Communication Technology (ICT) and teacher preparation for basic education. Journal of Teacher Education.

[10]. Osiakwan, E. M. (2002) Sustainable development without ICTs is not sustainable. Open Society Initiative ICT and Civil Society Consultative Meeting.

[11]. Rahamn, I. (2002) Strengthening information technology infrastructures in Bangladesh. In M.A.G. Akale (Ed) Science Technology and Mathematics Education for sustainable development in Africa. Ibadan STAN Pub.

[12]. Ukpebor, N. J. (2006) The use of Information Communication Technology as instruction materials Implication for secondary schools. ABACUS: The Journal of the Mathematics Association of Nigeria 31

[13]. Utor, Z. S. and Agbi, A. (2005) Realising the Benefit of ICT in Science and Technical Education through enhance library services. A paper presented at the Annual Conference of the School of Science, College of Education, Ekiadotor - Benin 